\title{
Efficacy and Safety of Percutaneous Endoscopic Gastrostomy in Elderly Patients Aged Over 65: A Tertiary Center Long-term Results
}

\author{
- (- Mustafa Zanyar Akkuzu, • Orhan Sezgin, • Enver Ucbilek, ๑ Ferzan Aydin, \\ - Hatice Rizaoglu Balci, ๑ Serkan Yaras, ๑ Osman Ozdogan, ๑ Fehmi Ates, ๑ Engin Altintas
}

Mersin University Faculty of Medicine, Department of Internal Medicine and Gastroenterology, Mersin, Turkey

Abstract

\begin{abstract}
Aim: Percutaneous endoscopic gastrostomy (PEG) is a method that can be applied for nutritional purposes in patients who cannot be fed orally for various reasons but whose gastrointestinal system functions are normal. In this study, we aimed to determine the etiological causes and long-term outcomes (efficacy, safety, lifespan) of PEG in patients over 65 years of age.

Methods: The data of patients aged 65 years or older who had PEG in our unit between 2015 and 2019 were analyzed retrospectively. The demographic information of the patients, the units they are being followed in, the underlying diseases, additional diseases, if any, complications-related to the procedure and the average life span were evaluated.

Results: During this period, 140 patients had been PEG inserted. $51 \%$ of patients were male and the average age was $73.7 \pm 9.2$ years, and the average age of women was $76 \pm 7.2$ years. The most frequent cause of PEG insertion is a neurological disease. PEG insertion was the most common in cerebrovascular events, with a rate of 39\%. PEG was implanted in 30\% for Alzheimer's disease, and $14 \%$ for malignant reasons. $28 \%$ of the patients lived less than a month. In total, $76 \%$ of patients died. The average life expectancy of patients who died after PEG was 221.3 \pm 330.7 days.
\end{abstract}

Conclusion: PEG is the gold standard in patients with normal gastrointestinal system functions in long-term enteral nutrition. However, in patients with a life expectancy of less than 1 month, the decision to place PEG or not should be made carefully.

Keywords: Percutaneous endoscopic gastrostomy, indication, complication, nutrition, senility

\section{Introduction}

Initially developed by Gauderer and Ponsky in 1980, Percutaneous endoscopic gastrostomy (PEG) is a method that can be applied for nutritional purposes in cases who have healthy gastrointestinal system functions but cannot feed orally for various reasons (1). Today, it is particularly used in patients who demonstrate insufficient oral intake, receive nasogastric tube feeding, at high risk of aspiration pneumonia and mostly in patients who have chronic neurological diseases (2). With being a surgical procedure, gastrostomy tube placement can be carried out under general anesthesia and morbidity rates ranging from 6 to $25 \%$ have been reported (3). However, PEG insertion is a cheaper, more practical and less risky method compared to surgical gastrostomy since it can be performed under local anesthesia and intravenous sedation even without the use of the endoscopy unit.

Enteral feeding has multiple advantages over parenteral feeding in patients who need long-term nutrition support, such as being more economical, easier and more convenient, requiring no central venous route, protecting the intestinal flora, preventing mucosal atrophy, reducing bacterial translocation, and maintaining intestinal immune response. Long-term use of nasogastric, nasodudenal and nasojejunal methods in patients undergoing prolonged enteral feeding has various complications such as nasopharyngeal discomfort, nasal erosion, acute otitis media, acute sinusitis, pharyngeal ulcer, esophagitis, esophageal ulcer, esophageal perforation, gastric erosion and ulceration $(4,5)$. 
In this study, we aimed to determine the etiological causes and long term outcomes (efficacy, safety, lifespan) of PEG in patients over 65 years of age.

\section{Methods}

\section{Study Design}

In this study, the data of geriatric patients aged 65 and over who had a PEG tube inserted at the clinic between 2015 and 2019 were analyzed retrospectively. Study data were collected from the endoscopy unit's data bank and patient files. Informed consent forms were obtained from all patients or relatives before procedures. Nurture Ethics committee approval was obtained for our study from the Mersin University Medical Faculty ethics committee on 22.01.2020 (resolution no: 56).

\section{PEG Technique}

Prior to the procedure, patients underwent an endoscopy to evaluate whether there were any anatomical pathologies in the stomach or duodenum that may obstacle PEG procedure. All PEG procedures were performed using sedation with local nasopharyngeal lidocaine and parenteral midazolam and, when required, under general anesthesia in some patients in the endoscopy unit with antibiotic prophylaxis, after the oral intake was stopped for a minimum of 6 hours. The patients were monitored and some patients who needed oxygen supplements were delivered. PEG tube was placed in all patients using the "Pull Technique (Gauderer Ponsky)" (1). Accompanied by two physicians and nurses, one of whom performed the endoscopic procedures, another performed PEG insertion in the epigastric site. The procedure was performed in compliance with the sterilization policy and the ideal antrum-corpus junction was detected using finger palpation with the endoscopic light that is visible through the skin. Flexible gastroscope (different brands) and various types of commercially available 16-20 Fr PEG sets were used. After the procedure, the patients' relatives who would nurture the patient were provided with detailed information about enteral nutrition, tube cleaning, and cleaning of surrounding tissue. Feeding through the gastrostomy was initiated approximately 4 hours after the procedure. Polymeric enteral nutrition formulas were used in the nutritional treatment of patients.

\section{Statistical Analysis}

The statistical analysis was carried out using SPSS version 21.0 software. Patients' data were given as mean \pm standard deviation, while categorical data as percentage.

\section{Results}

A total of 140 patients included in the study. Of our patients, 72 (51\%) were male and 68 (49\%) were female. The average total age was $74.5 \pm 8.4$ years.
The top three departments that referred the patients to our clinic for PEG insertion was neurology, which ranked first with 116 (83\%) patients, followed by medical oncology [14 (10\%) patients], and otorhinolaryngology clinic [5 (3.5\%) patients], respectively. All clinics are shown in detail in Table 1.

When we examined the reasons for PEG insertion; cerebrovascular events were the leading cause in 55 (39\%) patients. PEG was inserted in 42 (30\%) patients due to Alzheimer and dementia, $14(10 \%)$ due to Parkinson's disease, $6(4.3 \%)$ patients due to amyotrophic lateral sclerosis (ALS), and 3 (2\%) patients due to cerebral palsy. PEG insertion was carried out due to malignant reasons in $14.3 \%$ of the patients. Further information and additional associated diseases are given in Table 1.

During PEG insertion, there were no acute complications associated with upper gastrointestinal system endoscopy and PEG insertion. During follow-up, the tubes of 33 (23.5\%) patients were dislodged and replaced on standard PEG replacement time due to puncture and wear (Table

\begin{tabular}{|c|c|c|}
\hline & Parameters & Number (\%) \\
\hline & Mean age & \\
\hline Male & $73.7 \pm 9.2$ & $72(51)$ \\
\hline Female & $76 \pm 7.2$ & $68(49)$ \\
\hline Total & $74.5 \pm 8.4$ & $140(100)$ \\
\hline \multirow{5}{*}{$\begin{array}{l}\text { Clinics where cases } \\
\text { referred }\end{array}$} & Neurology & $116(83)$ \\
\hline & Medical oncology & $14(10)$ \\
\hline & Otorhinolaryngology & $5(3.5)$ \\
\hline & Neurosurgeon & $3(2)$ \\
\hline & General surgery & $2(1.5)$ \\
\hline \multirow{8}{*}{ Etiology } & Cerebrovascular diseases & $55(39)$ \\
\hline & $\begin{array}{l}\text { Dementia and Alzheimer's } \\
\text { disease }\end{array}$ & $42(30)$ \\
\hline & Parkinson's disease & $14(10)$ \\
\hline & Amyotrophic lateral sclerosis & $6(4.3)$ \\
\hline & Cerebral palsy & $3(2)$ \\
\hline & Esophageal tumor & $4(2.9)$ \\
\hline & Laryngeal cancer & $4(2.9)$ \\
\hline & $\begin{array}{l}\text { Other malignancies (Lung } 3 \text {, } \\
\text { tongue tumor } 3 \text {, tongue tumor } \\
3 \text {, colon } 2, \text { brain } 1 \text {, malignant } \\
\text { melanoma } 1 \text { ) }\end{array}$ & $12(8.5)$ \\
\hline \multirow{6}{*}{ Additional diseases } & Essential hypertension & $26(18.5)$ \\
\hline & Diabetes mellitus & $15(11)$ \\
\hline & Coronary artery disease & $15(11)$ \\
\hline & Chronic kidney disease & $5(3.5)$ \\
\hline & $\begin{array}{l}\text { Chronic obstructive pulmonary } \\
\text { disease }\end{array}$ & $4(3)$ \\
\hline & Chronic atrial fibrillation & $3(2)$ \\
\hline
\end{tabular}


2). Five (3.5\%) patients developed purulent discharge and abscess at the PEG site after an average of $268 \pm 100$ days. It was treated with local treatment and antibiotic use, and then catheter was replaced. Local bleeding developed at the PEG site in $3(2 \%)$ patients, because they pulled the PEG catheters themselves. It was brought under control with a local compression. The buried bumper syndrome also occurred in these patients and afterward, they were treated. In one patient $(0.7 \%)$, peritonitis developed due to the leakage around the PEG site and the patient died despite having a surgical operation in the follow-up. One hundred seven patients $(76.5 \%)$ did not develop complications and/or did not show up for PEG tube replacement: 22 patients had a new PEG tube inserted in the last 6 months and 11 of them were alive. In addition, there was no problem developed among the living: a total of 96 patients died during the period, including 62 patients in less than six months. However, there were no complications associated with PEG.

One hundred ten (76\%) of the patients died and 30 (24\%) were still alive. The mean age of the living was $72.7 \pm 7.3$ years. The average life span of the deceased patients after PEG insertion was $221.3 \pm 330.7$ days and their mean age was $74.5 \pm 8.5$ years. When we examined all the deceased patients, cerebrovascular diseases ranked first with 44 patients. There were 28 Alzheimer patients,

\begin{tabular}{|c|c|c|}
\hline & Parameters & Number (\%) \\
\hline \multirow{6}{*}{$\begin{array}{l}\text { PEG } \\
\text { complications }\end{array}$} & $\begin{array}{l}\text { Natural causes such as puncture } \\
\text { and wear on the PEG tube, normal } \\
\text { replacement time }\end{array}$ & $24(17)$ \\
\hline & $\begin{array}{l}\text { Drainage, abscess, infection at PEG } \\
\text { site }\end{array}$ & $5(3.5)$ \\
\hline & $\begin{array}{l}\text { Local bleeding as a result of buried } \\
\text { PEG or patients pulling PEG tube } \\
\text { themselves }\end{array}$ & $3(2)$ \\
\hline & $\begin{array}{l}\text { Peritonitis due to leakage around } \\
\text { PEG site }\end{array}$ & $1(0.7)$ \\
\hline & Total complication & $33(23.5)$ \\
\hline & $\begin{array}{l}\text { Recently deceased or newly inserted } \\
\text { PEG tube }\end{array}$ & $107(76.5)$ \\
\hline \multirow{4}{*}{$\begin{array}{l}\text { Life span of } \\
\text { cases }\end{array}$} & $\begin{array}{l}\text { Total living patient } \\
\text { Mean age } 72.7 \pm 7.3 \\
\end{array}$ & $30(24)$ \\
\hline & $\begin{array}{l}\text { Total deceased patient } \\
\text { Mean age } 74.5 \pm 8.5 \\
\text { Mean life span } 221.3 \pm 330.7 \text { days }\end{array}$ & $110(76)$ \\
\hline & $\begin{array}{l}\text { Life span less than } 1 \text { Month mean } \\
\text { age } 76 \pm 8.7 \\
\text { Mean life span } 15.5 \pm 8.2 \text { days }\end{array}$ & $40(28)$ \\
\hline & $\begin{array}{l}\text { Life span less than } 6 \text { months } \\
\text { Mean age } 75.6 \pm 8.6 \\
\text { Life span } 51.3 \pm 55.6 \text { days }\end{array}$ & $70(50)$ \\
\hline \multicolumn{3}{|c|}{ PEG: Percutaneous endoscopic gastrostomy } \\
\hline
\end{tabular}

12 with Parkinson's disease, 3 with ALS, 3 with cerebral palsy and 18 with malignant diseases. While the mean time of death in patients with malignant diseases was $206 \pm 282$ days, the mean time of death in neurological events were $223 \pm 340$ days.

A total of $70(50 \%)$ patients lived less than six months. Forty (28\%) of these patients also survived for less than a month. The mean age of patients surviving less than one month was $76 \pm 8.7$ years and the average life span was $15.5 \pm 8.2$ days. The mean age of all patients who lived less than six months was 75.6 \pm 8.6 years and the mean life span was $51.3 \pm 55.6$ days (Table 2 ).

\section{Discussion}

Providing nutritional support for patients is one of the most important points of treatment. PEG has also been a milestone for nutritional support in patients who have a healthy gastrointestinal tract but cannot feed orally. Enteral feeding via PEG should generally be used in patients who cannot take it orally for more than 1 month. The need for PEG is higher in elderly patients, as neurological complications and frequency of malignancy increase exponentially with age. In our study, gastrointestinal tract continuity was normal in all patients who underwent PEG. We did not confront technical difficulties and complications during the application.

It is found that the patients having a PEG tube inserted mostly had neurological problems (86\%). This was followed by patients with tumors. Therefore, neurology (83\%) was the first among the departments that referred patients for PEG insertion. Oncology ranked second with a frequency of $10 \%$. Cerebrovascular diseases were in the first place among neurological diseases that require PEG insertion. Dementia, Alzheimer's disease and Parkinson's disease were also among the common reasons. The results of our study were generally compatible with the large series published across the world and in our country (6-9). Our observations show that neurologists are conscious of and work in harmony with PEG application.

Contraindications for PEG include previous abdominal operation, coagulopathy, morbid obesity, presence of severe ascites, peritonitis, peritonitis carcinomatosa, laryngeal or esophageal obstructions $(10,11)$. None of our patients had contraindication for PEG insertion.

While 30-day mortality rates after the PEG procedure were $8-20 \%(12-14)$ in foreign series, the mortality rate was reported as $10-26.8 \%(10,15)$ in our country. Late mortality rates were reported as $15.7-67 \%(10,16)$. A study conducted by Malmgren et al. (16) reported the 6 month mortality rate as $56 \%$, while a study by Ermis et al. (10) reported $30 \%$. In our group, $76 \%$ of the patients who underwen PEG insertion died. The average life span of the 
deceased after PEG insertion was $221.3 \pm 330.7$ days. Our one-month mortality rate was $28 \%$ and 6 month mortality rate was $50 \%$.

Eighteen out of 20 patients with malignancy died at follow-up, and the life span of this group was $206 \pm 282$ days. The mean age of patients with malignancy was $67.9 \pm 5.5$ years. We believe that decision-making process for nutrition, especially in cancer patients, should be carried out for each individual, taking into account the patient's symptoms, performance status, estimated life expectancy, and the willingness or preferences of the patients in particular. Approximately one-third of our patients died within 1 month. Placing a PEG tube in patients whose life expectancy is considered to be less than 1 month is a case that needs special consideration. If required, nasogastric or parenteral feeding can be done during this period. Thus, patients can elude unnecessary risks and expenditures. The fact that our patients were old and that they had concomitant diseases had a significant effect on the life span of our patients. Most of our patients who developed complications were older men.

In the literature, $1-3 \%$ of deaths were reported to be associated with the PEG procedure (17-21). In our study, there was a procedure-related death in $1(0.7 \%)$ patient. Peritonitis due to leakage around the PEG tube resulted in the patient's death despite surgery.

Over time, the PEG tube may harden, become colored, develop irregular torsion, and an unpleasant odor may occur. Tubes must be replaced when they begin to cause problems such as barriers limiting the feeding, breaks or leaks (22). PEG replacement was done in $23.5 \%$ of all our patients. In $17 \%$ of those patients, PEG replacement was done for reasons such as puncture and wear on the PEG tube. Since the need for nutrition through PEG tube remained for some of our patients, PEG catheters were regularly replaced. PEG complications were also the cause in $6.5 \%$ of our patients that led to catheter replacement.

Complications related to the procedure can be observed during or after the PEG procedure. PEGrelated complications include peristomal pain, wound infection, abscess, necrotizing fasciitis, bleeding, pneumoperitoneum, colon or small bowel perforation, splenic or liver laceration, intraperitoneal hemorrhage, buried bumper syndrome and gastroparesis, aspiration and diarrhea. In the literature, procedure-related mortality rate is reported as $1-3 \%$, major complication rate is $6 \%$, and minor complication rate is between $12 \%$ and $55 \%$ (23). In accordance with the literature, a total of $6.5 \%$ of complications developed in our cases.

PEG-related wound infections occur in 5-25\% of patients. Usually, significant erythema, tenderness and purulent exudate develop in the PEG area (24). In 3.5\% of our patients, wound infection such as discharge and abscess developed at the PEG site. All our patients received prophylactic antibiotics. There is consensus in the literature on the use of antibiotic prophylaxis for PEG, and antibiotic prophylaxis significantly reduces the PEG tube insertion site infections $(25,26)$. In the case of infection, appropriate antibiotic therapy and local antiseptic and frequent dressing changes can help treat minor infections $(27,28)$. In our patients who developed an infection, PEG tube was replaced after the infection treatment.

Bleeding is a rare, often early complication after PEG placement. It may be hematoma or melena or unexplained anemia, hypotension. Buried PEG bumper syndrome as a different complication is potentially serious and occurs in roughly $1 \%$ of patients underwent PEG tube insertion. The internal support (bumper) moves through the gastrostomy tract in the stomach and abdominal wall to the surroundings and settles anywhere along the way (24). Even if asymptomatic, a buried bumper should be removed after diagnosis because continuous migration of the bumper may cause bleeding, perforation, peritonitis and death, eventually (29). $2 \%$ of our patients had buried PEG and bleeding was observed at the local PEG site as a result of pulling PEG tubes. However, this was treated with the interventions.

Gastrointestinal complications may include diarrhea, nausea, vomiting or insufficiency, aspiration, obstipation, cramps and bloating. Necessary symptomatic treatment such as appropriate nutritional feeding and prokinetics should be given. The best way to prevent long-term complications is to provide good care at home with detailed information given to the patient relatives. We believe that it is very important to follow up these patients at home and in the hospital by a specialized nutrition team.

\section{Study Limitations}

The limitation of our study was that it was retrospective. Therefore, we could only access the long-term follow-up and complications of the patients from the hospital data system.

\section{Conclusion}

The PEG tube insertion is an affordable, safe and practical feeding method that can be inserted in a short time, applied even at the bedside, has low morbidity and mortality rates, and shortens hospital stay. In patients whose life expectancy is considered to be less than 1 month, it is necessary to consider their special conditions to make a decision.

\section{Authorship Contributions}

Concept: M.Z.A., O.S., Design: M.Z.A., O.S., Data Collection or Processing: F.A., H.R.B., S.Y., O.O., Analysis or Interpretation: F.A., E.U., E.A., Literature Search: M.Z.A., S.Y., E.U., O.O., Writing: M.Z.A., O.S. 
Conflict of Interest: No conflict of interest was declared by the authors.

Financial Disclosure: The authors declared that this study received no financial support.

\section{References}

1. Gauderer MW, Ponsky JL, Izant RJ Jr. Gastrostomy without laparotomy: a percutaneous endoscopic technique. J Pediatr Surg 1980;15:872-5.

2. Kumar S, Langmore S, Goddeau RP Jr, et al. Predictors of percutaneous endoscopic gastrostomy tube placement in patients with severe dysphagia from an acute-subacute hemispheric infarction. J Stroke Cerebrovasc Dis 2012;21:11420.

3. Beaver ME, Myers JN, Griffenberg L, Waugh K. Percutaneous fluoroscopic gastrostomy tube placement in patients with head and neck cancer. Arch Otolaryngol Head Neck Surg 1998; 124:1141-4.

4. Marik PE, Zaloga GP. Early enteral nutrition in acutely ill patients: a systematic review. Crit Care Med 2001;29:226470.

5. Bassem YS, Jeffrey MM, Jeffrey LP. Percutaneous endoscopic gastros- tomy. Lightdale CJ, (eds). Gastrointestinal endoscopy, Philadelphia: WB Saunders Company 1998;551-63.

6. Fortunato JE, Troy AL, Cuffari $C$, et al. Outcome after percutaneous endoscopic gastrostomy in children and young adults. J Pediatr Gastroenterol Nutr 2010;50:390-3.

7. Srinivasan R, Irvine T, Dalzell M. Indications for percutaneous endoscopic gastrostomy and procedure-related outcome. J Pediatr Gastroenterol Nutr 2009;49:584-8.

8. Ekin N, Uçmak F, Oruç M, Tuncer ET, Yalçın K. Perkutan endoskopik gastrostomi uygulama sonuçlarımız: 113 olgunun değerlendirilmesi. Dicle Tıp Dergisi 2015;42:346-9.

9. Alper E, Baydar B, Arı FÖ, et al. Perkütan endoskopik gastroenterostomi uygulama deneyimlerimiz: Endikasyon ve komplikasyonlar. Akademik Gastroenteroloji Dergisi 2009;8:74-6

10. Ermis F, Ozel M, Oncu K, et al. Indications, complications and long-term follow-up of patients undergoing percutaneous endoscopic gastrostomy: A retrospective study. Wien Klin Wochenschr 2012;124:148-53.

11. Nadir I, Türkay C. Uzun Süreli Enteral Beslenmede Etkili ve Güvenilir Yaklaşım: Perkütan Endoskopik Gastrostomi. Güncel Gastroenteroloji 2011;15:95-7.

12. Nicholson FB, Korman MG, Richardson MA. Percutaneous endoscopic gastrostomy: a review of indications, complications and outcome. J Gastroenterol Hepatol 2000;15:21-5.

13. Skelly RH, Kupfer RM, Metcalfe ME, et al. Percutaneous endoscopic gastrostomy (PEG): change in practice since 1988. Clin Nutr 2002;21:389-94.

14. Kobayashi K, Cooper GS, Chak A, Sivak MV Jr, Wong RC. A prospective evaluation of outcome in patients referred for PEG placement. Gastrointest Endosc 2002;55:500-6.
15. Erdil A, Tüzün A, Saka $M$, ve ark. Perkütan endoskopik gastrostomi uygulamalarımız ve sonuçları. Gülhane Tıp Dergisi 2001;43:379-83

16. Malmgren A, Hede GW, Karlström B, et al. Indications for percutaneous endoscopic gastrostomy and survival in old adults. Food Nutr Res 2011;55:1-5.

17. Ateş F, Karıncaoğlu M, Aladağ M. Perkütan Endoskopik Gastrostomi Uygulanan Olgularda Erken Dönemde Görülen Komplikasyonların Malnütrisyonla ilişkisi Var Mı? Turgut Özal Tip Merk Derg 2008;15:169-174.

18. Cortez-Pinto H, Correia AP, Camilo ME, Tavares L, De Moura MC. Long-term management of percutaneous endoscopic gastrostomy by a nutritional support team. Clin Nutr 2002;21:27-31

19. Finocchiaro C, Galletti R, Rovera G, et al. Percutaneous endoscopic gastrostomy: a long-term follow-up. Nutrition 1997;13:520-3.

20. Kayaoğlu H, Özkan N, Ersoy ÖF, Çelik A. Perkütan endoskopik gastrostominin nadir bir komplikasyonu: Burried Bumper Sendromu Türkiye Klinikleri J Med Sci 2007;27:618-21.

21. Tok $D$, Ok $G$, Erbüyün $K$, Ertan $Y$, Çetin. Yoğun Bakım Ünitesinde Perkutan Endoskopik Gastrostomi Uygulamaları Dicle Tip Der 2006;2:81-84.

22. DeLegge $\mathrm{MH}$. Gastrostomy tubes: complications and their management. UpToDate 2018

23. Varnier A, Iona L, Dominutti MC, et al. Percutaneous endoscopic gastrostomy: complications in the short and long-term follow-up and efficacy on nutritional status. Eura Medicophys 2006;4223-6.

24. Hucl T, Spicak J. Complications of percutaneous endoscopic gastrostomy. Best Pract Res Clin Gastroenterol 2016;30:76981.

25. Jain NK, Larson DE, Schroeder KW, et al. Antibiotic prophylaxis for percutaneous endoscopic gatrostomy: A prospective, randomized controlled clinical trial. Ann Intern Med 1987; 107:824-8.

26. Pien EC, Hume KE, Pien FD. Gastrostomy tube infections in a community hospital. Am J Infect Control 1996;24:353-8.

27. Lipp A, Lusardi G. Systemic antimicrobial prophylaxis for percutaneous endoscopic gastrostomy. Cochrane Database Syst Rev 2013;2013:5571.

28. Blumenstein I, Borger D, Loitsch S, et al. A glycerin hydrogelbased wound dressing prevents peristomal infections after percutaneous endoscopic gastrostomy (PEG): a prospective, randomized study. Nutr Clin Pract 2012;27:422-5.

29. Ma MM, Semlacher EA, Fedorak RN, et al. The buried gastrostomy bumper syndrome: prevention and endoscopic approaches to removal. Gastrointest Endosc 1995;41:505-8. 